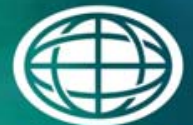

Savannah River

National Laboratory "m

\title{
DWPF SMECT PVV Sample Characterization and Remediation
}

Christopher J. Bannochie, Ph.D.

Charles L. Crawford, Ph.D.

Fellow Scientists

SRNL-STI-2013-00289 
SRNL-STI-2013-00289

Revision 0

\section{DISCLAIMER}

This work was prepared under an agreement with and funded by the U.S. Government. Neither the U.S. Government or its employees, nor any of its contractors, subcontractors or their employees, makes any express or implied:

1. warranty or assumes any legal liability for the accuracy, completeness, or for the use or results of such use of any information, product, or process disclosed; or

2. representation that such use or results of such use would not infringe privately owned rights; or

3. endorsement or recommendation of any specifically identified commercial product, process, or service.

Any views and opinions of authors expressed in this work do not necessarily state or reflect those of the United States Government, or its contractors, or subcontractors.

\section{Printed in the United States of America \\ Prepared for U.S. Department of Energy}


Keywords: DWPF, SMECT, PVV, Characterization

Retention: Permanent

\title{
DWPF SMECT PVV Sample Characterization and Remediation
}

\author{
C. J. Bannochie \\ C. L. Crawford
}

May 2013 


\section{REVIEWS AND APPROVALS}

\section{AUTHORS:}

C. J. Bannochie, Process Technology Programs

Date

C. L. Crawford, Process Technology Programs

Date

TECHNICAL REVIEW:

J. R. Zamecnik, Process Technology Programs, Reviewed per E7, 2.60 Date

APPROVAL:

D. R. Click, Manager

Date

Process Technology Programs

Date

S.L. Marra, Manager

Environmental \& Chemical Process Technology Research Programs

E. J. Freed, Manager

Date

DWPF Facility Engineering 


\section{ACKNOWLEDGEMENTS}

The authors wish to acknowledge the assistance of Dr. Chris Martino for photographs taken and for assistance in some aspects of this work while the authors were unavailable. We also acknowledge the assistance of Dr. Chuck Coleman in preparing materials for the digestions and all the Shielded Cells personnel for supporting this work including preparing samples and testing the material. 


\section{EXECUTIVE SUMMARY}

On April 2, 2013, a solid sample of material collected from the Defense Waste Processing Facility's Process Vessel Vent (PVV) jumper for the Slurry Mix Evaporator Condensate Tank (SMECT) was received at the Savannah River National Laboratory (SRNL). DWPF has experienced pressure spikes within the SMECT and other process vessels which have resulted in processing delays while a vacuum was re-established. Work on this sample was requested in a Technical Assistance Request (HLW-DWPFTAR-2013-002). This document reports the results of chemical and physical property measurements made on the sample, as well as insights into the possible impact to the material using remediation methods proposed by DWPF. DWPF was interested in what the facility could expect when the material was exposed to either $8 \mathrm{M}$ nitric acid or $90 \%$ formic acid, the two materials they have the ability to flush through the PVV line in addition to process water once the line is capped off during a facility outage.

Based upon the SRNL analysis of the SMECT PVV jumper sample material, the following conclusions are put forth:

a) The sample material is a heterogeneous mixture of crystalline and noncrystalline species comprising approximately $82 \mathrm{wt} . \%$ total solids.

b) The order of abundance of elements in the sample is: $\mathrm{Hg}>>\mathrm{Al}>\mathrm{Fe}>\mathrm{Si}>\mathrm{Th}>\mathrm{Ni}$. The $\mathrm{Hg}$ species is non-crystalline and was not identified.

c) The material is completely solubilized using a peroxide fusion digestion; mostly solubilized with a hot, pressurized aqua regia digestion leaving primarily Bohmite $[\mathrm{AlO}(\mathrm{OH})]$ undissolved; partially solubilized with $8 \mathrm{M}$ nitric acid leaving predominately Bohmite and Magnetite $\left[\mathrm{Fe}_{3} \mathrm{O}_{4}\right]$ undissolved along with other trace species; and a bit less partially solubilized with $90 \%$ formic acid leaving predominately Bohmite, Magnetite, and $\mathrm{Hg}$ species undissolved along with other trace species.

d) The dissolution test with $8 \mathrm{M}$ nitric acid resulted in significant dissolution of $\mathrm{Hg}$ from the material and an overall mass reduction of $\sim 52 \%$.

e) The dissolution test with $90 \%$ formic acid resulted in far less $\mathrm{Hg}$ dissolution from the material, as compared to the $8 \mathrm{M}$ nitric acid test, and an overall mass reduction of $\sim 31 \%$.

Of the two proposed remediation methods presented by DWPF to soak and flush the PVV line jumper, $8 \mathrm{M}$ nitric acid and $90 \%$ formic acid, our testing indicates the $8 \mathrm{M}$ nitric acid will have the most impact of the two. The nitric acid will dissolve at least an order of magnitude more $\mathrm{Hg}$ from the material, though some sludge components and frit present in the material will remain. The impact of a subsequent pressurized water rinse of the line could not be simulated, so its efficacy in removing the undissolved solids is unclear.

The collection and analysis of a sample of the $8 \mathrm{M}$ nitric acid soak/flush solution following contact with the line could be informative in assessing the relative success of the remediation effort. If the rinse is free of $\mathrm{Hg}$ and other elements, there was no pluggage material to remove. If the rinse contains significant $\mathrm{Hg}$ and/or solids one could conclude that there are contaminants present in the jumper line. Should the flush sample come back positive for the presence of solids, further sampling might not be able to determine whether the PVV jumper line is clear of all materials after all flushing has been completed; this would require a visual inspection. 


\section{TABLE OF CONTENTS}

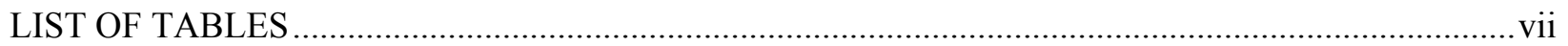

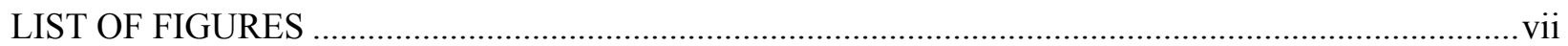

LIST OF ABBREVIATIONS AND ACRONYMS...........................................................................iii

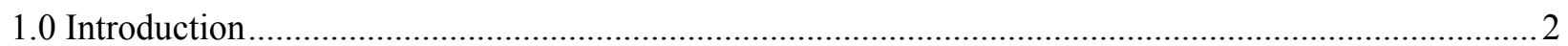

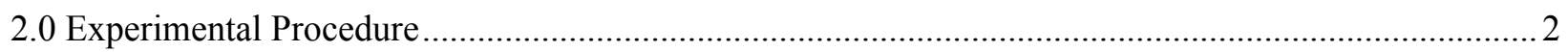

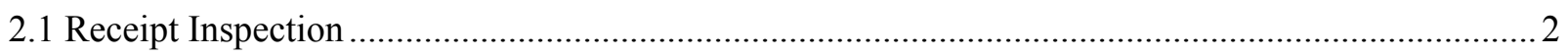

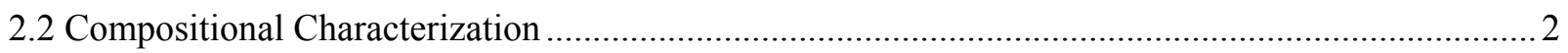

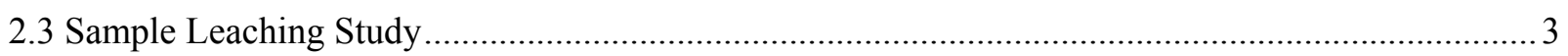

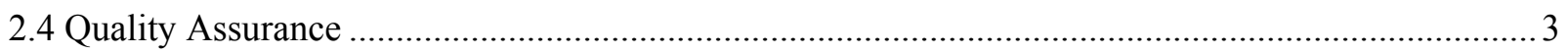

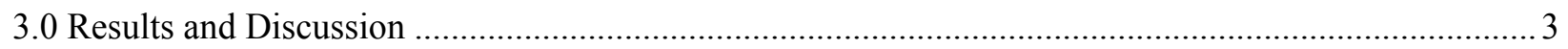

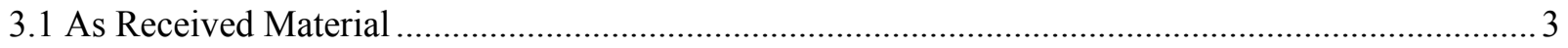

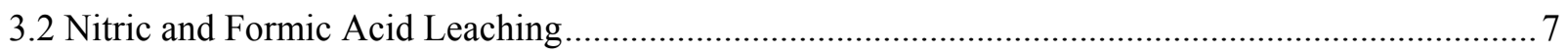

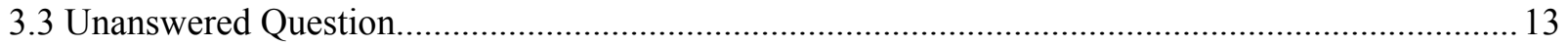

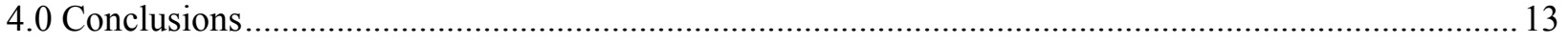

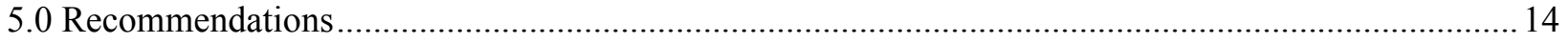

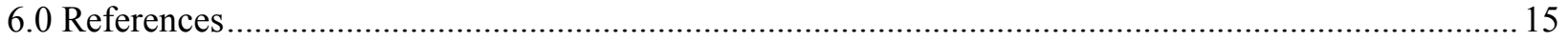


SRNL-STI-2013-00289

Revision 0

\section{LIST OF TABLES}

Table 3-1. Elemental Composition of the Digested DWPF SMECT PVV Sample in $\mathrm{Wt} \%$ of Total Dried Solids (\%RSD) [No. of Replicates]. Data obtained via ICP-AES unless otherwise indicated. . 6

Table 3-2. Elemental Composition in $\mathrm{mg} / \mathrm{L}$ of Leachate and $\mathrm{mg} / \mathrm{g}$ of Dissolved SMECT PVV Solids for the 8M Nitric Acid (N. A.) Leachate ......................................................................................... 7

Table 3-3. Elemental Composition in $\mathrm{mg} / \mathrm{L}$ of Leachate and $\mathrm{mg} / \mathrm{g}$ of Dissolved SMECT PVV Solids for the $90 \%$ Formic Acid (F. A.) Leachate 8

\section{LIST OF FIGURES}

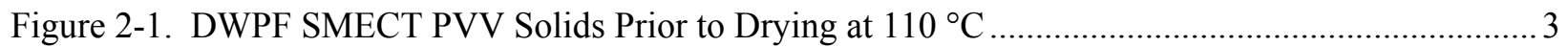

Figure 3-1. XRD Spectra of As-Received SMECT PVV Material......................................................... 4

Figure 3-2. SEM image showing area of raster scan where $\mathrm{Al}, \mathrm{Fe}, \mathrm{Hg}, \mathrm{Si}, \mathrm{Na}, \mathrm{K}, \mathrm{Ca}, \mathrm{Cu}$, and $\mathrm{Ni}$ were identified. Spot 2 is the Carbon Tape Background area that was scanned.

Figure 3-3. EDS spectra of large scan area shown in Figure 3-2 ....................................................... 5

Figure 3-4. EDS spectra of a spot analysis showing the presence of Th in the SMECT PVV sample....... 6

Figure 3-5. Leached solids collected from overnight exposure to $8 \mathrm{M}$ nitric acid. …............................... 8

Figure 3-6. Leached solids collected from overnight exposure to $90 \%$ formic acid................................ 9

Figure 3-7. XRD spectra of residual solids collected after an 8M nitric acid leach of DWPF SMECT PVV solids. 10

Figure 3-8. XRD spectra of residual solids collected after a $90 \%$ formic acid leach of DWPF SMECT PVV solids.

Figure 3-9. SEM image showing area of high Hg content (Spot 1) in nitric acid leached SMECT PVV solids.

Figure 3-10. EDS spectra from Spot 1 showing the presence of $\mathrm{Hg}$ in the post nitric acid leached SMECT PVV sample

Figure 3-11. SEM image showing area of high $\mathrm{Hg}$ content (Spot 1) in nitric acid leached SMECT PVV solids.....

Figure 3-12. SEM image showing areas of $\mathrm{Hg}$ content (Spot 4, 5, and 6) in nitric acid leached SMECT PVV solids. 


\section{LIST OF ABBREVIATIONS AND ACRONYMS}

$\begin{array}{ll}\text { AR } & \text { Aqua Regia } \\ \text { ARG } & \text { Analytical Reference Glass } \\ \text { CVAA } & \text { Cold Vapor Atomic Absorption Spectroscopy } \\ \text { DWPF } & \text { Defense Waste Processing Facility } \\ \text { EDS } & \text { Energy Dispersive X-Ray Spectroscopy } \\ \text { ICP-AES } & \text { Inductively Coupled Plasma - Atomic Emission Spectroscopy } \\ \text { ICP-MS } & \text { Inductively Coupled Plasma - Mass Spectroscopy } \\ \text { PF } & \text { Peroxide Fusion } \\ \text { PVV } & \text { Process Vessel Vent } \\ \text { SEM } & \text { Scanning Electron Microscopy } \\ \text { SMECT } & \text { Slurry Mix Evaporator Condensate Tank } \\ \text { SRNL } & \text { Savannah River National Laboratory } \\ \text { TAR } & \text { Technical Assistance Request } \\ \text { XRD } & \text { X-Ray Diffraction }\end{array}$


SRNL-STI-2013-00289

Revision 0

\subsection{Introduction}

On April 2, 2013, a solid sample of material collected from the Defense Waste Processing Facility's Process Vessel Vent (PVV) jumper for the Slurry Mix Evaporator Condensate Tank (SMECT) was received at the Savannah River National Laboratory (SRNL). DWPF has experienced pressure spikes within the SMECT and other process vessels which have resulted in processing delays while a vacuum was re-established. Work on this sample was requested in a Technical Assistance Request (TAR) ${ }^{1}$. This document reports the results of chemical and physical property measurements made on the sample, as well as insights into the possible impact to the material using DWPF's proposed remediation methods. DWPF was interested in what the facility could expect when the material was exposed to either $8 \mathrm{M}$ nitric acid or $90 \%$ formic acid, the two materials they have the ability to flush through the PVV line in addition to process water once the line is capped off during a facility outage.

\subsection{Experimental Procedure}

\subsection{Receipt Inspection}

The sample arrived at SRNL in a DWPF primary container marked PC-121 and was loaded into the Shielded Cells. It was comprised of $8.255 \mathrm{~g}$ of heterogeneous, both in color and grain size, solids which were mottled gray and crumbly in appearance. Bigger pieces of the material broke up easily, though some larger pieces did stick to the spatula during our attempt to homogenize the material prior to sampling for x-ray diffraction (XRD) and scanning electron microscopy (SEM), precluding the use of a mortar and pestle to further homogenize the material. The sample did not stick to the stainless steel primary container used to ship the container to SRNL.

\subsection{Compositional Characterization}

Three SEM probe tips were used to collect solids for analysis by Energy Dispersive x-ray Spectroscopy (EDS) and to obtain SEM images, and $102 \mathrm{mg}$ of material was submitted for XRD. The range of particle sizes for the material is shown in Figure 2-1 prior to drying and digestion for elemental analysis. The material was dried at $110{ }^{\circ} \mathrm{C}$ for several days prior to digestion by aqua regia $(A R)^{2}$ or alkali peroxide fusion $(\mathrm{PF})^{3}$. The AR digestions were done in triplicate along with an Analytical Reference Glass (ARG) ${ }^{4}$ and the PF digestions were conducted on a single sample to check the results obtained by the DWPF Laboratory. The AR digestions were analyzed by inductively coupled plasma - atomic emission spectroscopy (ICP-AES), inductively coupled plasma - mass spectroscopy (ICP-MS), and cold vapor atomic absorption (CVAA) spectroscopy for Hg. The PF digestion was analyzed by ICP-AES. 


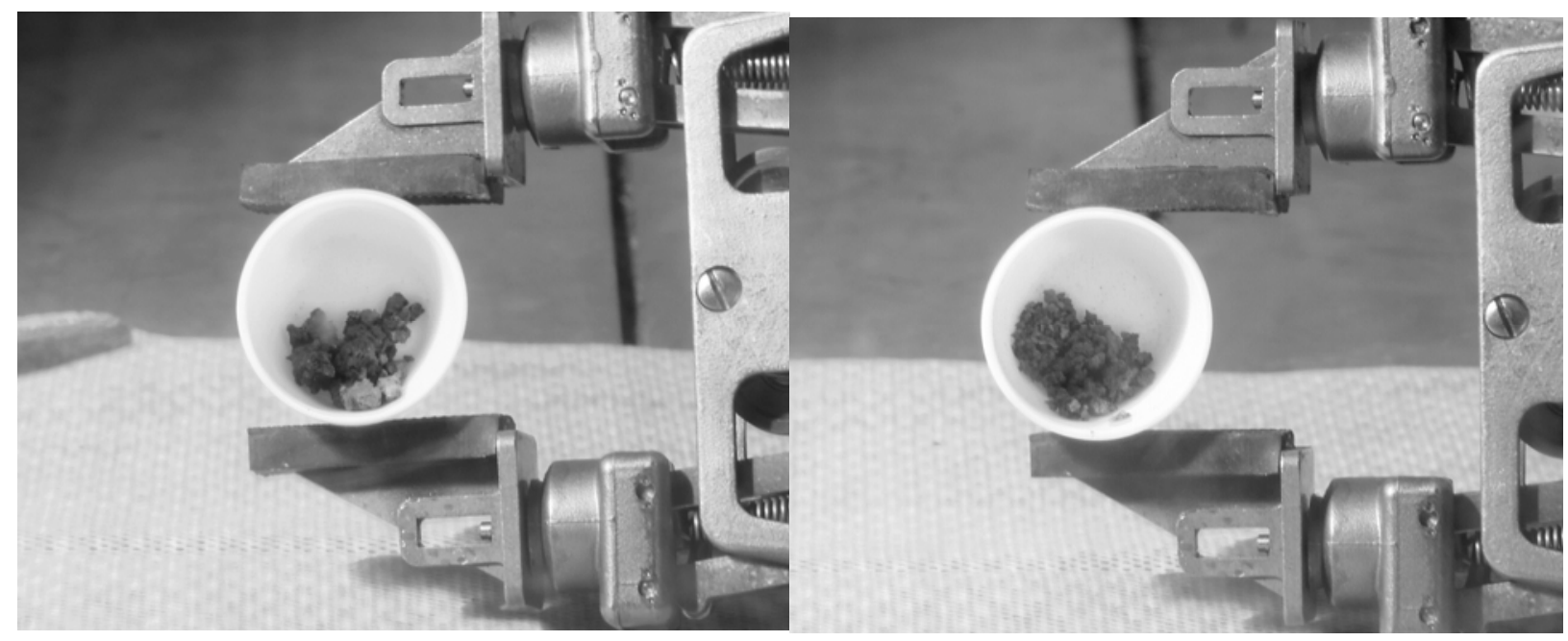

Figure 2-1. DWPF SMECT PVV Solids Prior to Drying at $110{ }^{\circ} \mathrm{C}$

\subsection{Sample Leaching Study}

SRNL exposed two samples of approximately $0.5 \mathrm{~g}$ each of undried SMECT PVV solids to $150 \mathrm{~mL}$ of $8 \mathrm{M}$ nitric acid and two separate $0.5 \mathrm{~g}$ samples to $90 \%$ formic acid overnight. The leachate was then analyzed by ICP-AES, ICP-MS and CVAA for $\mathrm{Hg}$, while the remaining solids were collected by vacuum filtration, rinsed with deionized water, air dried and submitted for SEM and XRD analyses. The mass of solids remaining following each of the leach tests was determined in order to calculate the percent of dissolution observed in each test.

\subsection{Quality Assurance}

Requirements for performing reviews of technical reports and the extent of review are established in manual E7 2.60. SRNL documents the extent and type of review using the SRNL Technical Report Design Checklist contained in WSRC-IM-2002-00011, Rev. 2.

\subsection{Results and Discussion}

\subsection{As Received Material}

The material when dried at $110{ }^{\circ} \mathrm{C}$ was approximately $82 \mathrm{wt} . \%$ total solids (\%RSD 7.6) with a range of $76-88$ wt. $\%$ for the three replicates.

The XRD spectra obtained for the as-received SMECT PVV material is shown in Figure 3-1. Two species are confirmed, Bohmite $[\mathrm{AlO}(\mathrm{OH})]$ and Magnetite $\left[\mathrm{Fe}_{3} \mathrm{O}_{4}\right]$, the remaining species shown in Figure 3-1 are speculative. A Hg compound is suspected in the material, but no match could be obtained in the spectral database. This is in contrast to the $\mathrm{Hg}$ that was found by XRD in the GC Line Filter Assembly and identified as a mixture of $\mathrm{Hg}_{4}(\mathrm{OH})\left(\mathrm{NO}_{3}\right)_{3}$ and $\mathrm{Hg}_{10}(\mathrm{OH})_{4}\left(\mathrm{NO}_{3}\right)_{6}{ }^{5}$. There are also a number of major unassigned peaks in the SMECT PVV sample spectrum. 


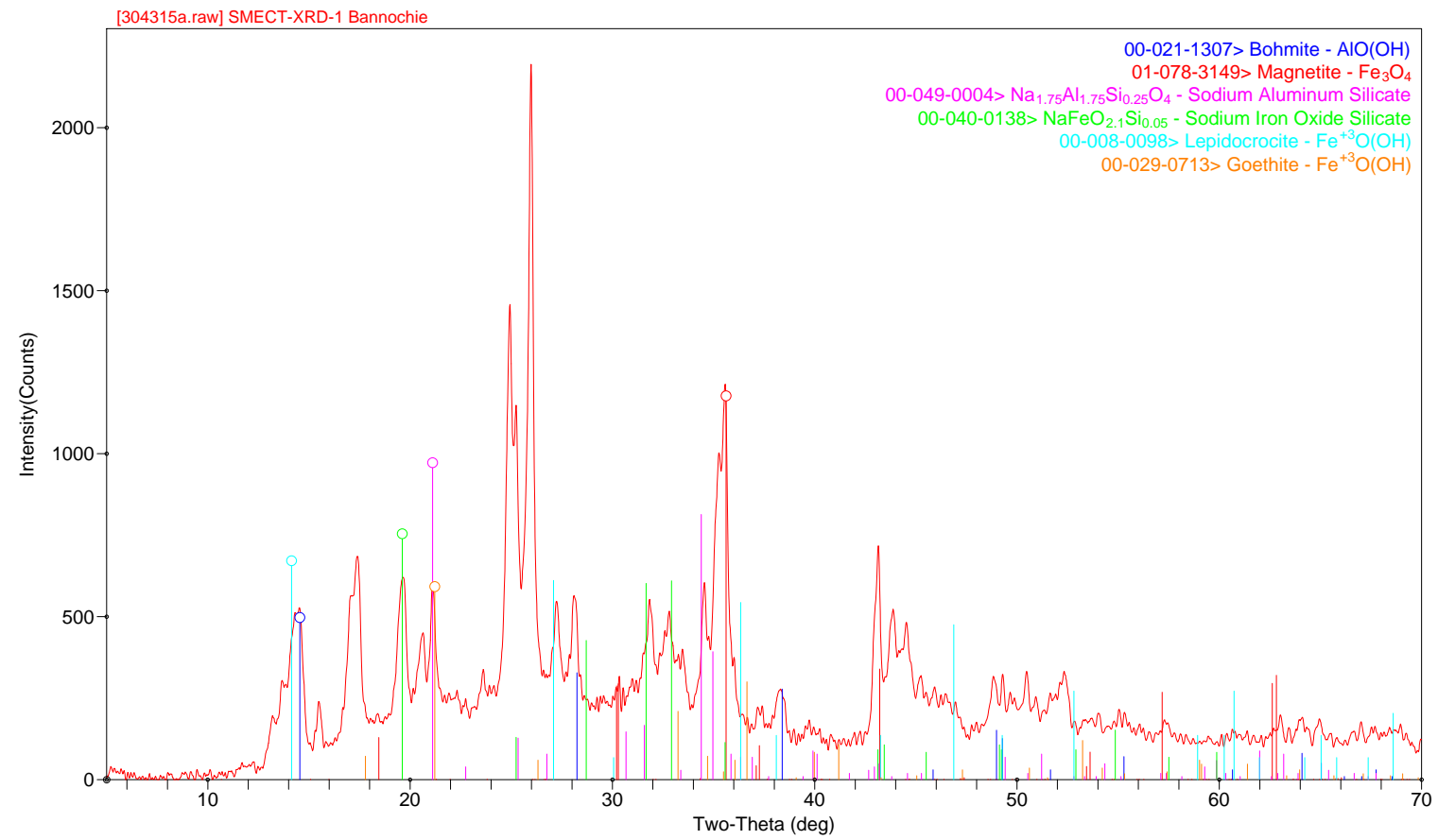

Figure 3-1. XRD Spectra of As-Received SMECT PVV Material

SEM images were captured for the as-received material collected on each of the three probes submitted. An EDS raster scan of the material indicated the presence of $\mathrm{Al}, \mathrm{Fe}, \mathrm{Hg}$, and $\mathrm{Si}$, and lesser amounts of $\mathrm{Na}$, $\mathrm{K}, \mathrm{Ca}, \mathrm{Cu}$, and $\mathrm{Ni}$. Spot analyses showed material that was primarily $\mathrm{Hg}$, a mixture of $\mathrm{Hg}$ and $\mathrm{Al} / \mathrm{Fe}$ silicates, Th containing species, Si species, and primarily Al species. The SEM image from which the raster scan was taken is shown in Figure 3-2, and Figure 3-3 provides the EDS spectra obtained for this scan area. 


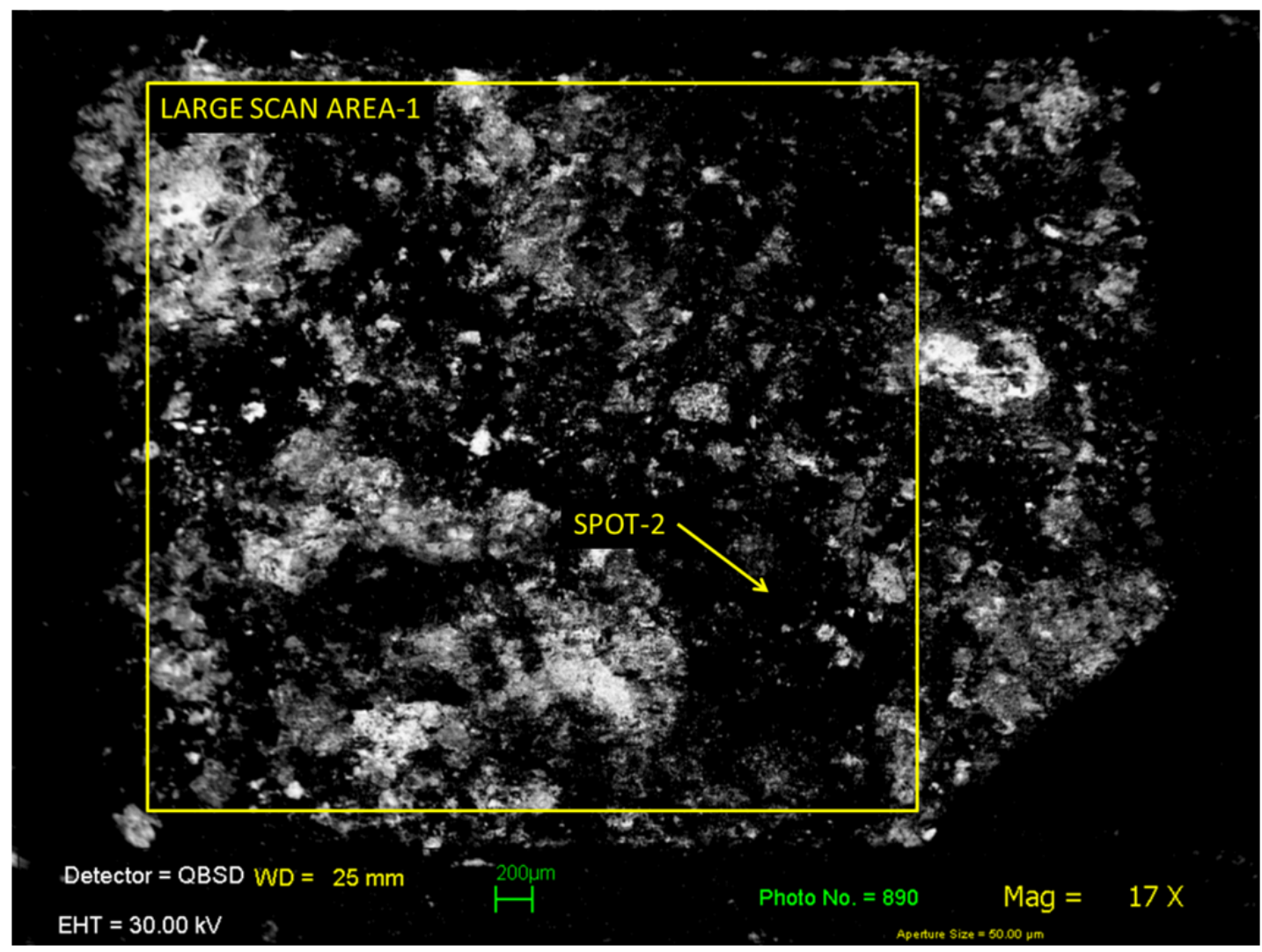

Figure 3-2. SEM image showing area of raster scans where $\mathrm{Al}, \mathrm{Fe}, \mathrm{Hg}, \mathrm{Si}, \mathrm{Na}, \mathrm{K}, \mathrm{Ca}, \mathrm{Cu}$, and Ni were identified. Spot 2 is the Carbon Tape Background area that was scanned.

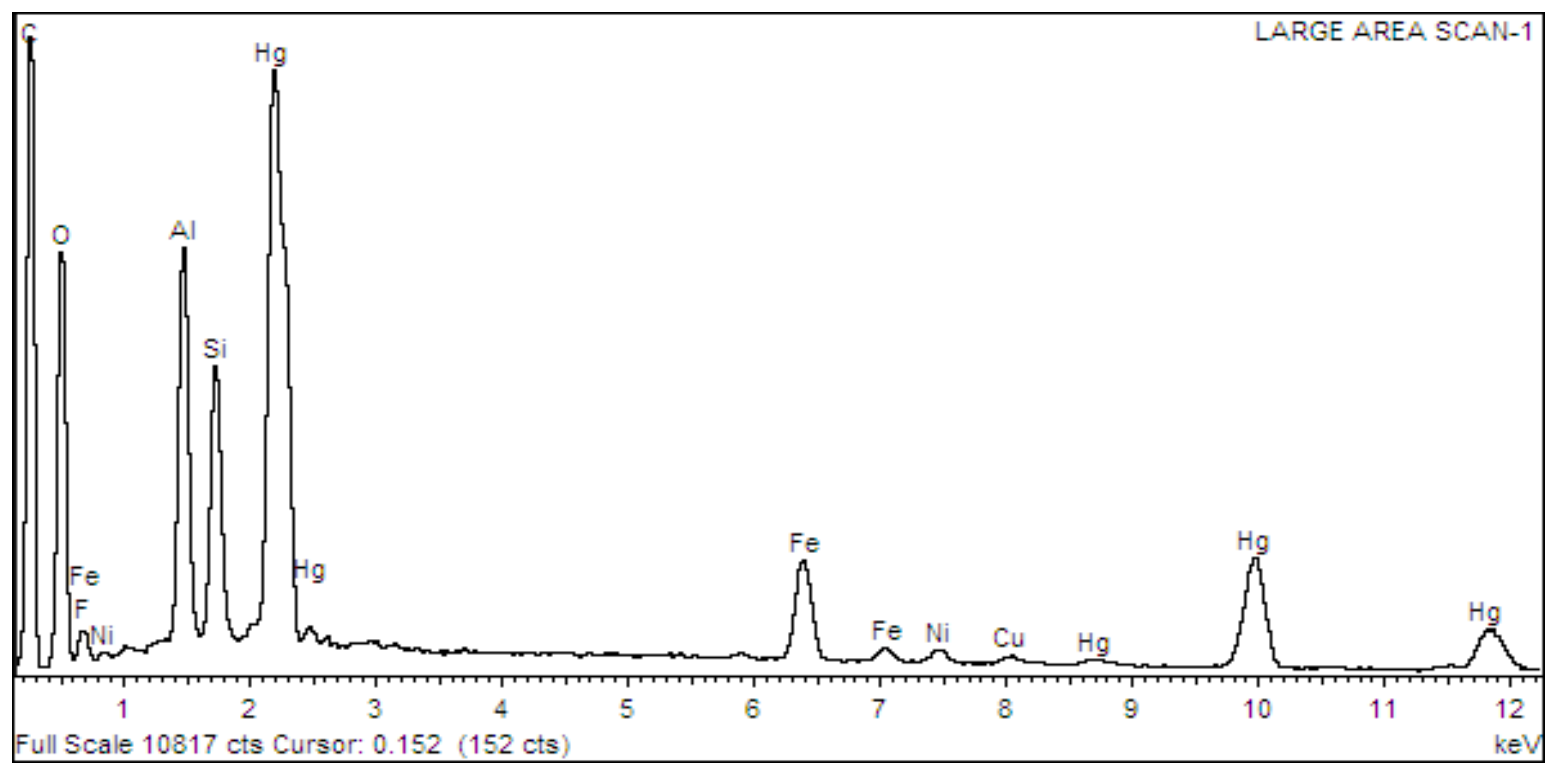

Figure 3-3. EDS spectra of large scan area shown in Figure 3-2.

Thorium was not identified in the raster scan shown in Figure 3-2, but it was identified in a number of EDS spot analyses taken on the submitted samples. Figure 3-4 shows one of the EDS spectra that 
identified the presence of Th in the material. In addition to the EDS spectra, ICP-AES and ICP-MS data collected from the AR digestion of the dried solids also indicated the presence of Th (Table 3-1).

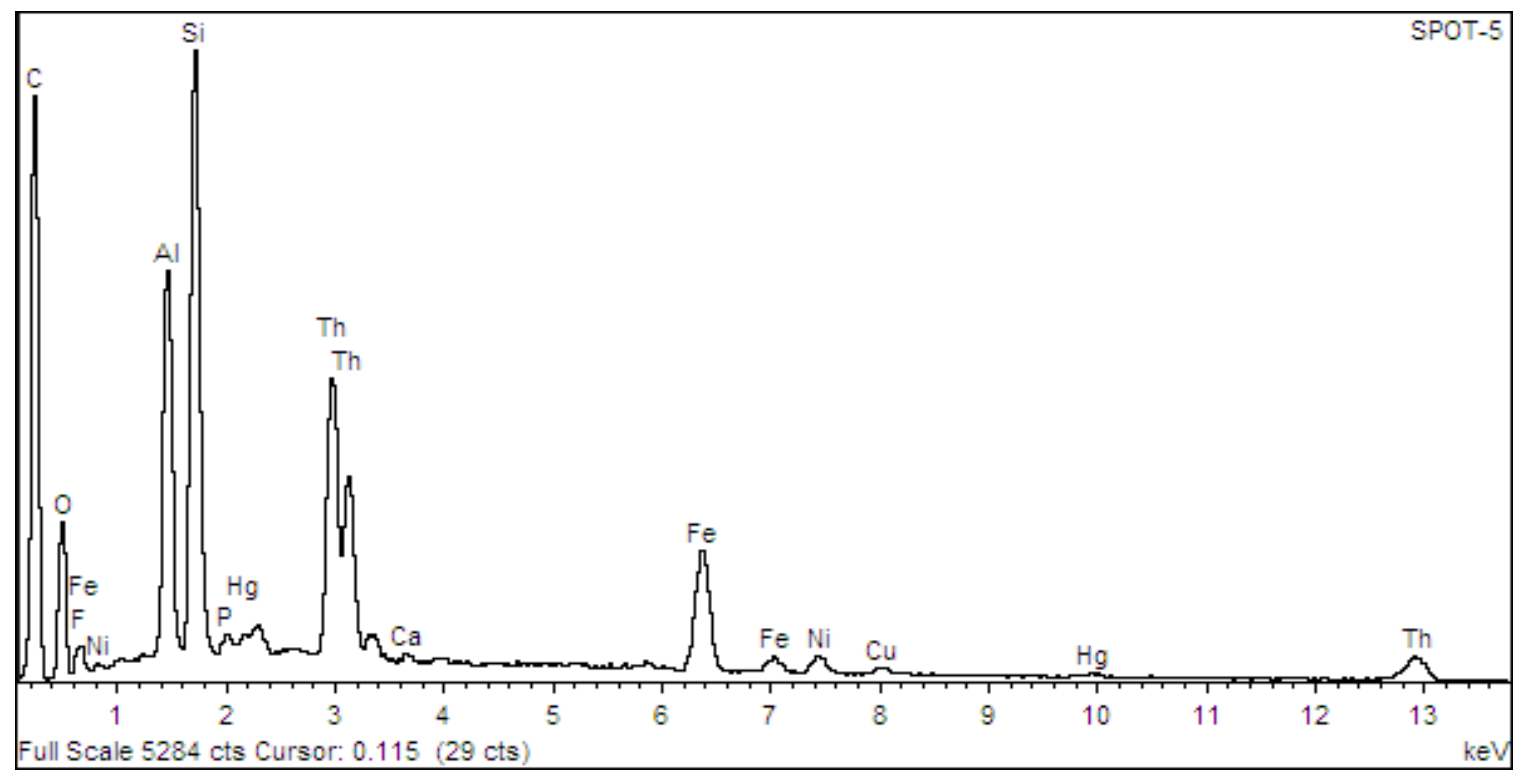

Figure 3-4. EDS spectra of a spot analysis showing the presence of Th in the SMECT PVV sample.

The elemental composition derived from measurements of digested sample at both DWPF and SRNL is summarized in Table 3-1. Unless otherwise indicated in the table the data was obtained by ICP-AES measurements. Values $\geq 0.1 \mathrm{wt} . \%$ as determined by at least one analytical method or laboratory are included in the table. The relative order of abundance of elements is $\mathrm{Hg}>>\mathrm{Al}>\mathrm{Fe}>\mathrm{Si}>\mathrm{Th} \approx \mathrm{Ni}$.

Table 3-1. Elemental Composition of the Digested DWPF SMECT PVV Sample in Wt.\% of Total Dried Solids (\%RSD) [No. of Replicates]. Data obtained via ICP-AES unless otherwise indicated.

\begin{tabular}{|c|c|c|c|}
\hline Element & $\begin{array}{c}\text { DWPF PF } \\
\text { wt.\% TS }\end{array}$ & $\begin{array}{c}\text { SRNL AR }^{b} \\
\text { wt.\% TS }\end{array}$ & $\begin{array}{r}\text { SRNL PF } \\
\text { wt.\% TS }\end{array}$ \\
\hline Al & $7.26(3.3)[4]$ & $2.96(18)[3]$ & $7.83[1]$ \\
\hline Ca & $\mathbf{0 . 0 3 9 3}(28)[4]$ & $\mathbf{0 . 0 2 5 2}(11)[3]$ & $0.301[1]$ \\
\hline $\mathrm{Cr}$ & $0.161(9.1)[4]$ & $0.0289(36)[3]$ & $0.0393[1]$ \\
\hline $\mathbf{F e}$ & $5.20(5.2)[4]$ & $4.42(18)[3]$ & $5.12[1]$ \\
\hline Hg & $22.9^{\mathrm{c}}(1.0)[2]$ & $\mathbf{1 6 . 3}^{\mathrm{d}}(8.2)[3]$ & NA \\
\hline Mn & $\mathbf{0 . 1 5 2}(8.5)[4]$ & $0.119(20)[3]$ & $\mathbf{0 . 1 5 0}[1]$ \\
\hline $\mathrm{Na}$ & NA & $\mathbf{0 . 0 9 9 4}(11)[3]$ & NA \\
\hline $\mathbf{N i}$ & $\mathbf{0 . 8 3 6}(6.6)[4]$ & $0.650(6.9)[3]$ & $0.764[1]$ \\
\hline $\mathbf{P}$ & NA & $\mathbf{0 . 0 9 0 0}(14)[3]$ & $D L^{f}$ \\
\hline Si & $3.76(9.8)[4]$ & NA & $2.63[1]$ \\
\hline Th & $0.746(7.3)[4]$ & $\mathbf{0 . 9 1 5}^{\mathbf{e}}(19)[3]$ & $1.00[1]$ \\
\hline $\mathbf{U}$ & $0.147(19)[4]$ & $\mathbf{0 . 0 6 1 6}^{\mathrm{e}}(9.2)[3]$ & $D L^{f}$ \\
\hline $\mathrm{Zr}$ & NA & $\mathbf{0 . 1 8 6}(13)[3]$ & NA \\
\hline
\end{tabular}

$\overline{\mathrm{NA}} \equiv$ Not Available, a) $\mathrm{PF} \equiv$ peroxide fusion, $\mathrm{b}) \mathrm{AR} \equiv$ aqua regia digestion, c) DWPF cold chem digestion analyzed with a $\mathrm{Hg}$ analyzer, d) CVAA, e) ICP-MS, f) Detection Limit

Values with the highest confidence level are shown in bold, but the heterogeneous nature of the solids analyzed may be the source of much of the uncertainty and variability in the data. 


\subsection{Nitric and Formic Acid Leaching}

Leachate samples from an overnight soak of the as-received SMECT PVV solids at room temperature in $8 \mathrm{M}$ nitric acid or $90 \mathrm{wt} . \%$ formic acid were collected and submitted for analysis as previously described in Section 2.3. The elemental results are shown in Table 3-2 for the nitric acid leach. Only constituents found at levels above the detection limit are provided in the table. The large amount of Th in the material resulted in ICP-AES interferences for $U$, so the $U$ concentrations were reported from ICP-MS measurements. There is a fair amount of variability between the two replicates which seems to support the heterogeneous nature of the material. For this reason the two replicate leach tests were not averaged.

Table 3-2. Elemental Composition in mg/L of Leachate and mg/g of Dissolved SMECT PVV Material for the 8M Nitric Acid (N. A.) Leachate

\begin{tabular}{ccccc}
\hline Element & $\begin{array}{c}\text { mg/L } \\
\text { Leachate } \\
\text { N. A. Repl. 1 }\end{array}$ & $\begin{array}{c}\text { mg/g } \\
\text { Dissolved Material } \\
\text { N. A. Repl. 1 }\end{array}$ & $\begin{array}{c}\text { mg/L } \\
\text { Leachate } \\
\text { N. A. Repl. 2 }\end{array}$ & $\begin{array}{c}\text { mg/g } \\
\text { Dissolved Material } \\
\text { N. A. Repl. 2 }\end{array}$ \\
\hline $\mathbf{A l}$ & 2.84 & 1.57 & 2.91 & 1.76 \\
$\mathbf{B a}$ & 0.129 & 0.0711 & 0.0752 & 0.0455 \\
$\mathbf{C a}$ & 0.800 & 0.441 & 0.480 & 0.290 \\
$\mathbf{C e}$ & 0.484 & 0.267 & 0.431 & 0.261 \\
$\mathbf{C r}$ & 0.107 & 0.0590 & 0.0742 & 0.0449 \\
$\mathbf{C u}$ & 0.120 & 0.0662 & 0.0868 & 0.0525 \\
$\mathbf{F e}$ & 21.1 & 11.6 & 13.7 & 8.29 \\
$\mathbf{H g}$ & 861 & 475 & 625 & 378 \\
$\mathbf{L a}$ & 0.0790 & 0.0436 & 0.0518 & 0.0313 \\
$\mathbf{L i}$ & 0.0824 & 0.0454 & 0.0398 & 0.0241 \\
$\mathbf{M g}$ & 0.186 & 0.103 & 0.564 & 0.341 \\
$\mathbf{M n}$ & 1.45 & 0.800 & 0.737 & 0.446 \\
$\mathbf{N a}$ & 4.35 & 2.40 & 2.57 & 1.55 \\
$\mathbf{N i}$ & 2.56 & 1.41 & 1.78 & 1.08 \\
$\mathbf{P}$ & 1.74 & 0.960 & 1.13 & 0.683 \\
$\mathbf{S i}$ & 1.54 & 0.849 & 1.04 & 0.629 \\
$\mathbf{S r}$ & 0.0221 & 0.0122 & 0.0133 & 0.00804 \\
$\mathbf{T h}$ & 4.61 & 2.54 & 4.67 & 2.82 \\
$\mathbf{T i}$ & 0.927 & 0.511 & 0.593 & 0.359 \\
$\mathbf{U} \mathbf{b}$ & 2.32 & 1.26 & 1.28 & 0.761 \\
$\mathbf{Z n}$ & 0.285 & 0.157 & 0.0947 & 0.0573 \\
$\mathbf{Z r}$ & 1.85 & 1.02 & 1.45 & 0.877 \\
\hline
\end{tabular}

a) CVAA, b) ICP-MS

By far the largest contributor to the dissolved mass is from $\mathrm{Hg}$ containing species. In the case of the $8 \mathrm{M}$ nitric acid leach, there was a loss of mass of $51 \%$ for Replicate 1 and $53 \%$ for Replicate 2.

The elemental results are shown in Table 3-3 for the formic acid leach. Again, only constituents found at levels above the detection limit are provided in the table. There was less variability between the two formic acid replicates than what was observed between the nitric acid replicates. During sample preparation prior to analysis, a 10x dilution of the formic acid leachate resulted in a cloudy solution, so a decision was made to analyze the sample with a 20x dilution, which produced a clear diluent. The high dilution relative to the nitric acid leachates $(2 x)$ resulted in the higher detection limits for many of the elements. The most notable difference when comparing the two data sets is the observation that far less 
$\mathrm{Hg}$ dissolved into the formic acid leaches than was recorded for the nitric acid leaches. Outside of $\mathrm{Hg}$, there were roughly equivalent amounts of $\mathrm{Al}, \mathrm{Ca}, \mathrm{Mn}, \mathrm{Na}$, and $\mathrm{Zn}$; far less $\mathrm{Fe}$, Th, and $\mathrm{U}$; and more $\mathrm{Si}$ dissolved by the formic acid leach. Excluding the difference in $\mathrm{Hg}$, there was roughly an equivalent mass of other elements dissolved in the two acids. In the case of the $90 \%$ formic acid leach, there was a loss of mass of $29 \%$ for Replicate 1 and 34\% for Replicate 2.

Table 3-3. Elemental Composition in $\mathrm{mg} / \mathrm{L}$ of Leachate and $\mathrm{mg} / \mathrm{g}$ of Dissolved SMECT PVV Solids for the $90 \%$ Formic Acid (F. A.) Leachate

\begin{tabular}{ccccc}
\hline Element & $\begin{array}{c}\text { mg/L } \\
\text { Leachate } \\
\text { F. A. Repl. 1 }\end{array}$ & $\begin{array}{c}\text { mg/g } \\
\text { Dissolved Solids } \\
\text { F. A. Repl. 1 }\end{array}$ & $\begin{array}{c}\text { mg/L } \\
\text { Leachate } \\
\text { F. A. Repl. 2 }\end{array}$ & $\begin{array}{c}\text { mg/g } \\
\text { Dissolved Solids } \\
\text { F. A. Repl. 2 }\end{array}$ \\
\hline $\mathbf{A l}$ & 2.74 & 3.00 & 2.95 & 2.68 \\
$\mathbf{C a}$ & 0.847 & 0.927 & 0.948 & 0.862 \\
$\mathbf{F e}$ & 8.05 & 8.81 & 8.56 & 7.78 \\
$\mathbf{H g}$ & 0.0963 & 0.105 & 0.0990 & 0.0900 \\
$\mathbf{M g}$ & 0.152 & 0.166 & 0.128 & 0.116 \\
$\mathbf{M n}$ & 1.15 & 1.26 & 0.979 & 0.890 \\
$\mathbf{N a}$ & 3.95 & 4.32 & 3.62 & 3.29 \\
$\mathbf{N i}$ & 1.28 & 1.40 & 1.20 & 1.09 \\
$\mathbf{S i}$ & 3.29 & 3.60 & 4.29 & 3.90 \\
$\mathbf{S r}$ & 0.0150 & 0.0164 & 0.0120 & 0.0109 \\
$\mathbf{T h}$ & 0.220 & 0.241 & 0.264 & 0.240 \\
$\mathbf{U}$ & 0.845 & 0.925 & 0.846 & 0.769 \\
$\mathbf{Z n}$ & 0.165 & 0.181 & 0.156 & 0.142 \\
\hline
\end{tabular}

a) CVAA, b) ICP-MS

The solids collected from each of the leaching characterizations are shown in Figure 3-5 and Figure 3-6. The solids did not "collapse" upon introduction and soaking in either acid. After they were recollected from the leachate, the solids remained tacky following rinsing with deionized water and air drying.

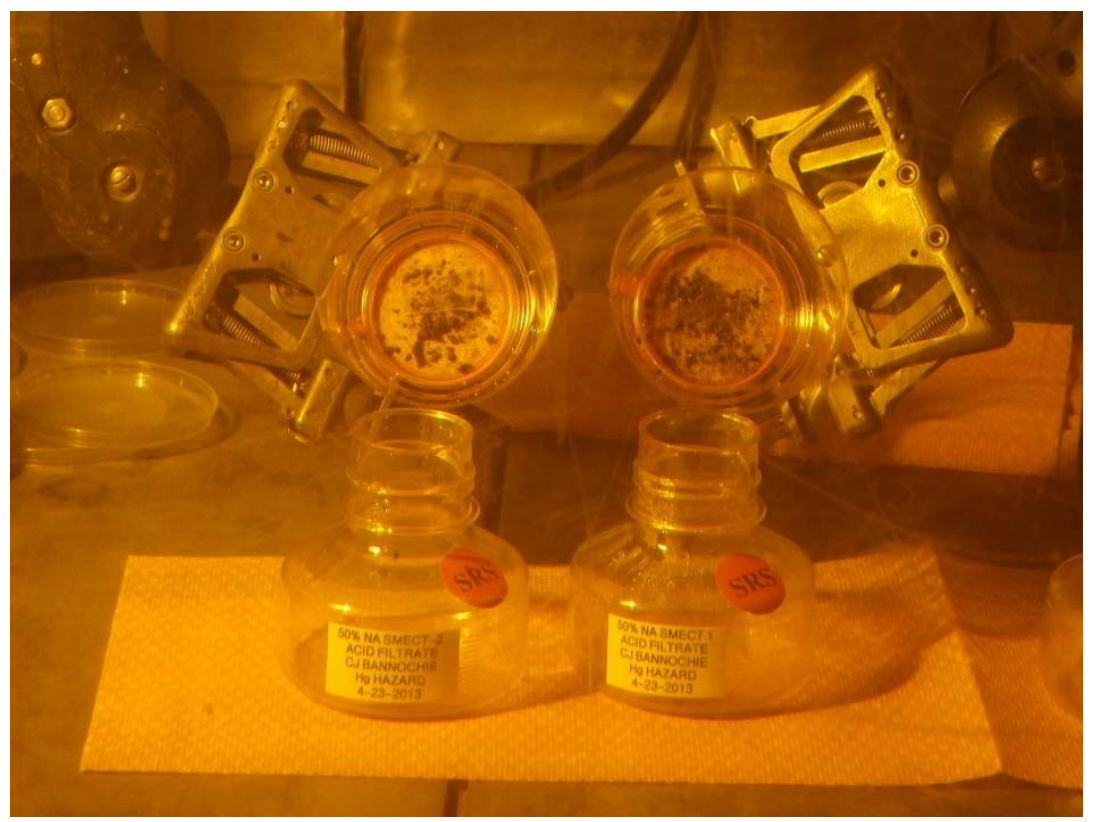

Figure 3-5. Leached solids collected from overnight exposure to 8M nitric acid. 


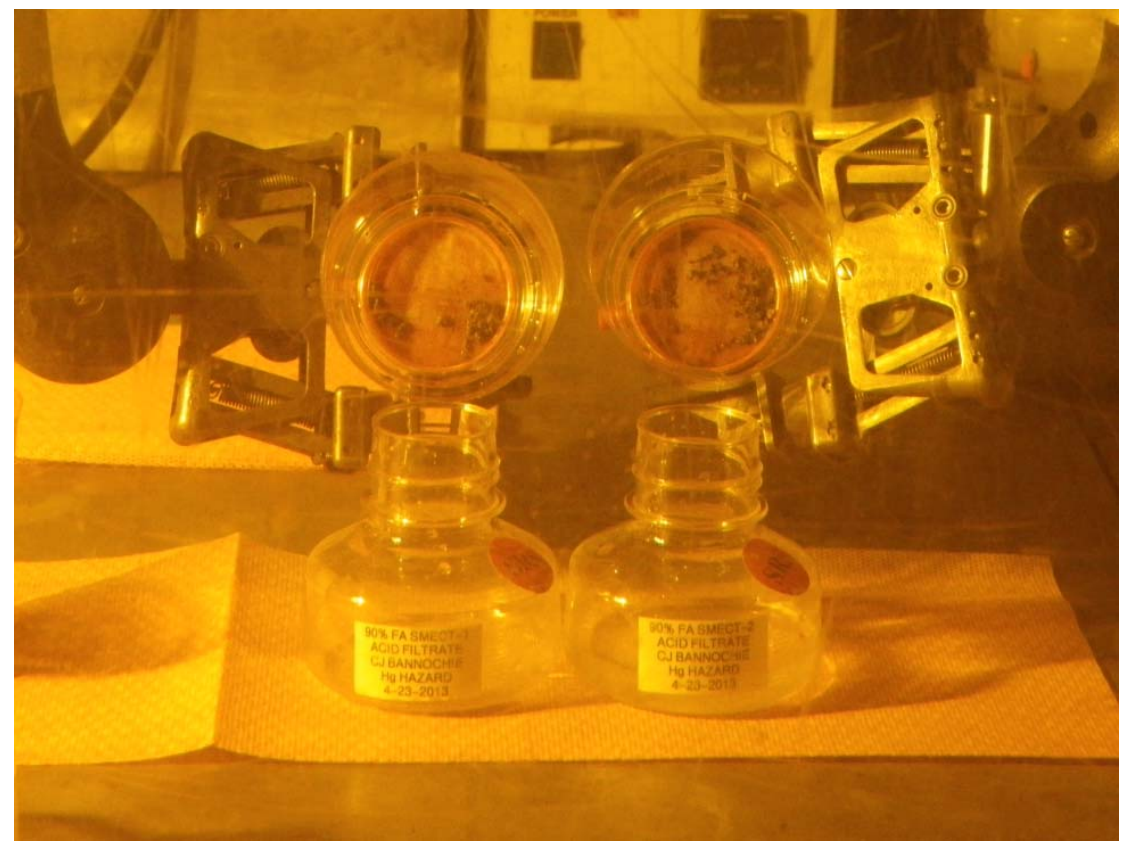

Figure 3-6. Leached solids collected from overnight exposure to $90 \%$ formic acid.

The solids collected from the leach analyses were submitted for XRD and SEM examination. The XRD spectra collected on the solids remaining following the nitric acid leach are shown in Figure 3-7 and those following the formic acid leach are shown in Figure 3-8. As was observed for the initial as-received SMECT PVV solids (Figure 3-1), the solids following both leach tests indicate the presence of Bohmite and Magnetite, along with a number of other absorption peaks which could not be assigned to structures in the spectral database.

The EDS examination of the SEM samples did show the presence of distinguishable $\mathrm{Hg}$ content despite the $8 \mathrm{M}$ nitric acid leach having preferentially dissolved $\mathrm{Hg}$ as demonstrated by the ICP-AES data presented previously in Table 3-2. Figure 3-9 shows the light areas of high Hg content (Spot 1) in a sample that was largely comprised of $\mathrm{Al}, \mathrm{Fe}$, and $\mathrm{Si}$ (Spots 2 and 3). It is unclear whether this area of $\mathrm{Hg}$ is due to undissolved $\mathrm{Hg}$ that may have dissolved if given longer exposure to the $8 \mathrm{M}$ nitric acid, or if it is a $\mathrm{Hg}$ species that was not removed when the leach solution was rinsed from the sample with deionized water, allowing it to reprecipitate on the other undissolved compounds during air drying of the sample prior to analysis. 
SRNL-STI-2013-00289

Revision 0

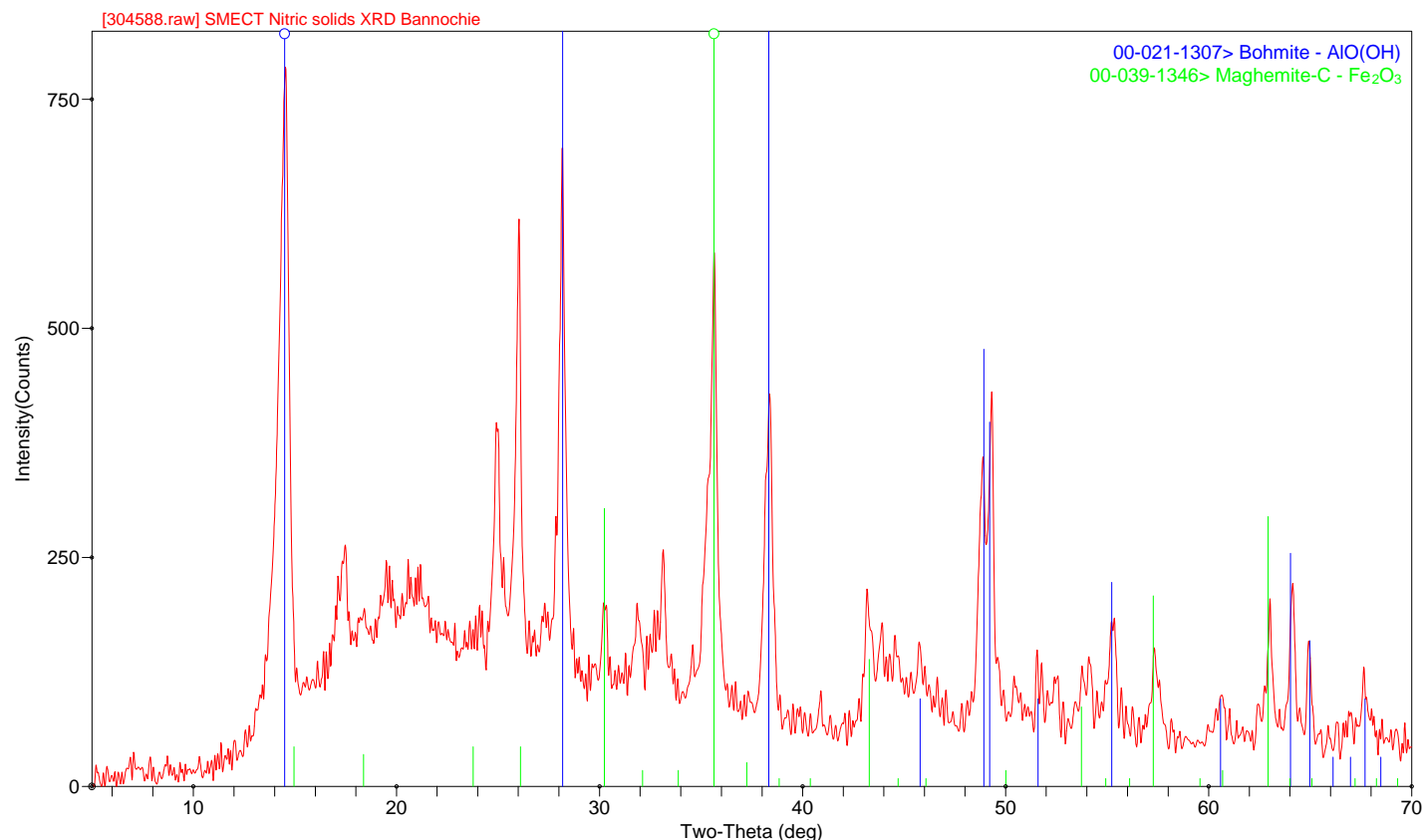

Figure 3-7. XRD spectra of residual solids collected after an 8M nitric acid leach of DWPF SMECT PVV solids.

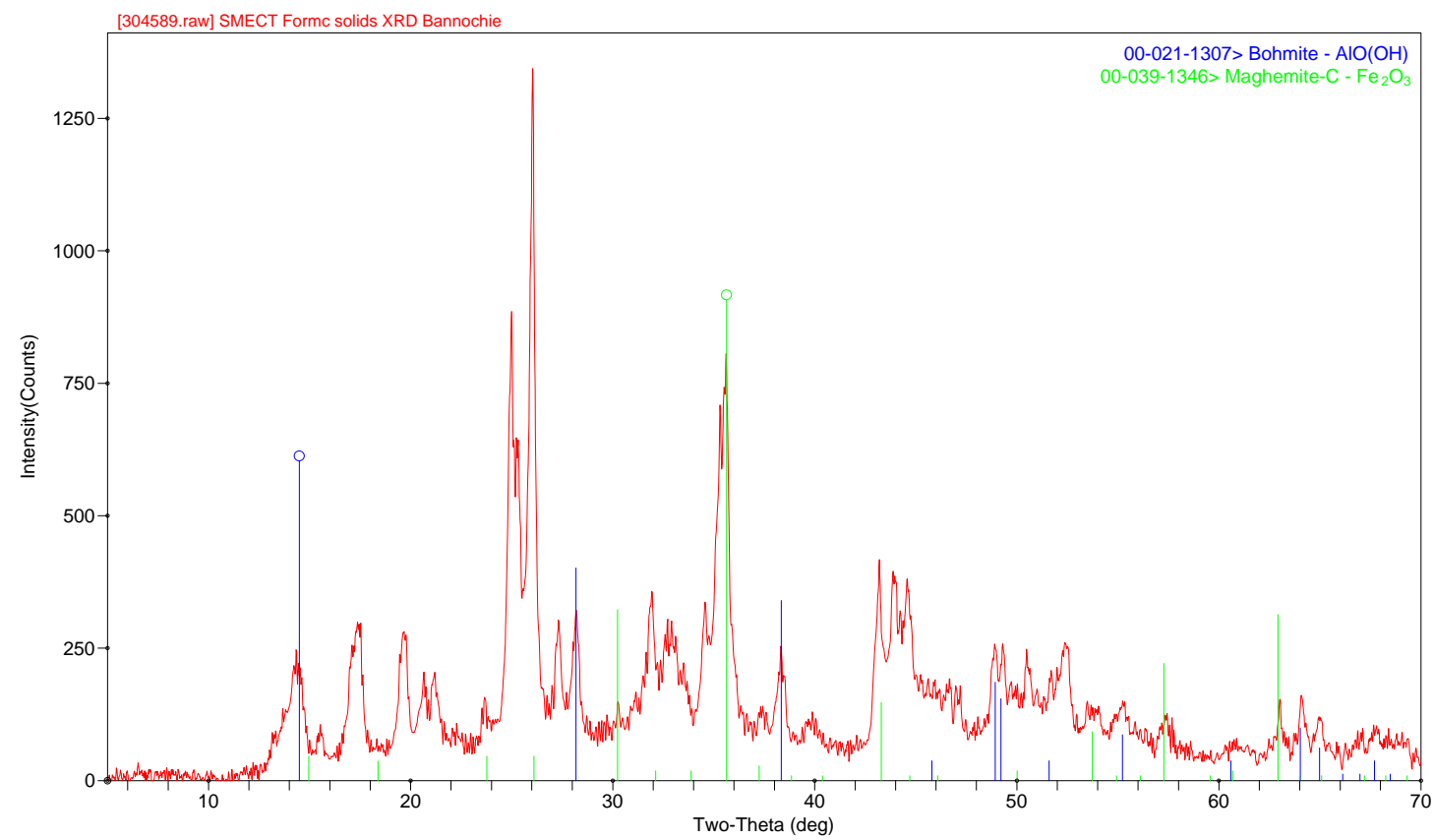

Figure 3-8. XRD spectra of residual solids collected after a $90 \%$ formic acid leach of DWPF SMECT PVV solids. 


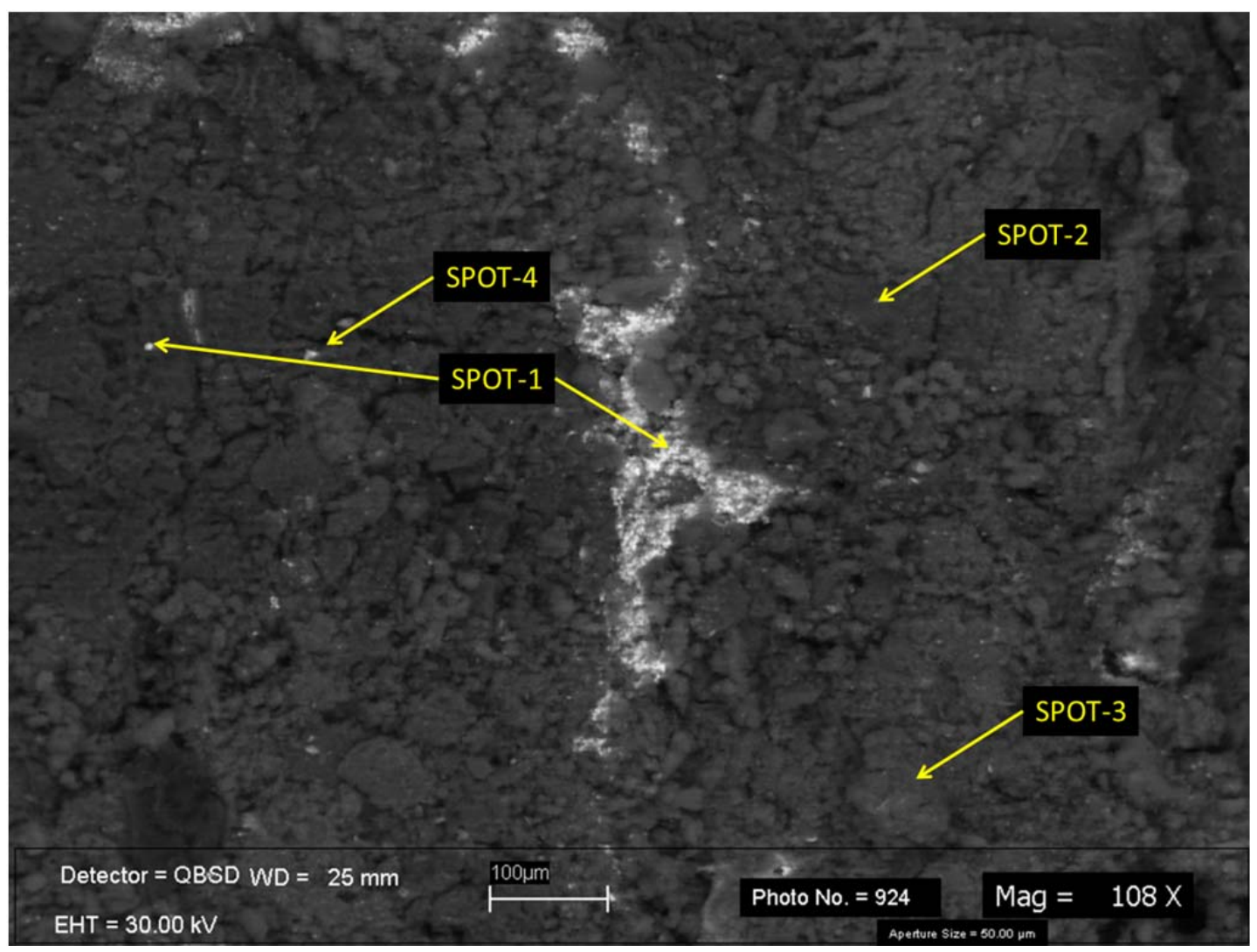

Figure 3-9. SEM image showing area of high Hg content (Spot 1) in nitric acid leached SMECT PVV solids.

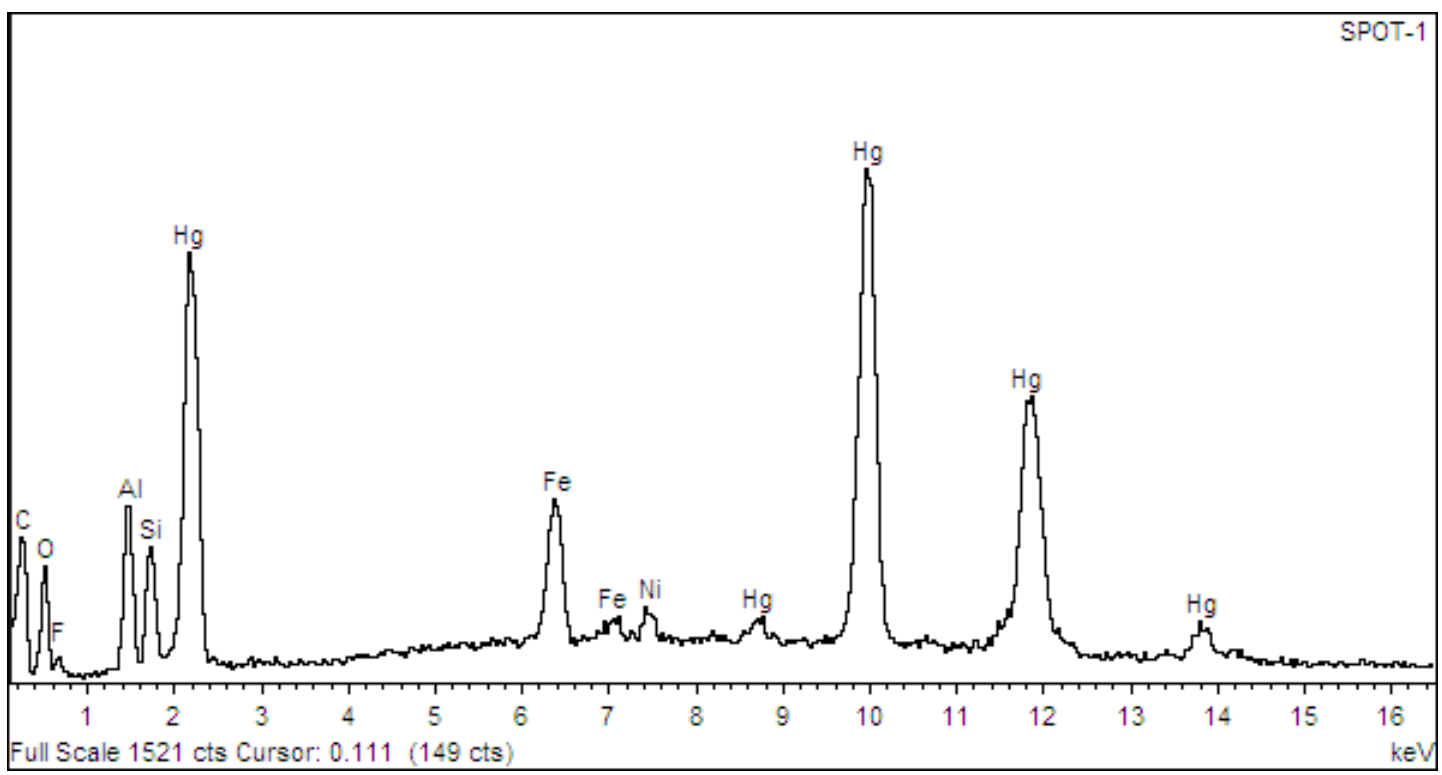

Figure 3-10. EDS spectra from Spot 1 showing the presence of $\mathrm{Hg}$ in the post nitric acid leached SMECT PVV sample 
The SMECT PVV solids collected following a 90\% formic acid leach and deionized water rinse showed broad areas of $\mathrm{Hg}$ containing compounds consistent with the much smaller dissolution of $\mathrm{Hg}$ that occurred from the sample when it was exposed to the formic acid leach (see data in Table 3-3). Spots labeled 1 in Figure 3-11 indicate primarily $\mathrm{Hg}$ containing compounds, as do Spots $4-6$ in Figure 3-12. The remaining spots (2 and 3) were primarily $\mathrm{Al}$ and $\mathrm{Si}$ containing materials, possibly resulting from entrained frit.

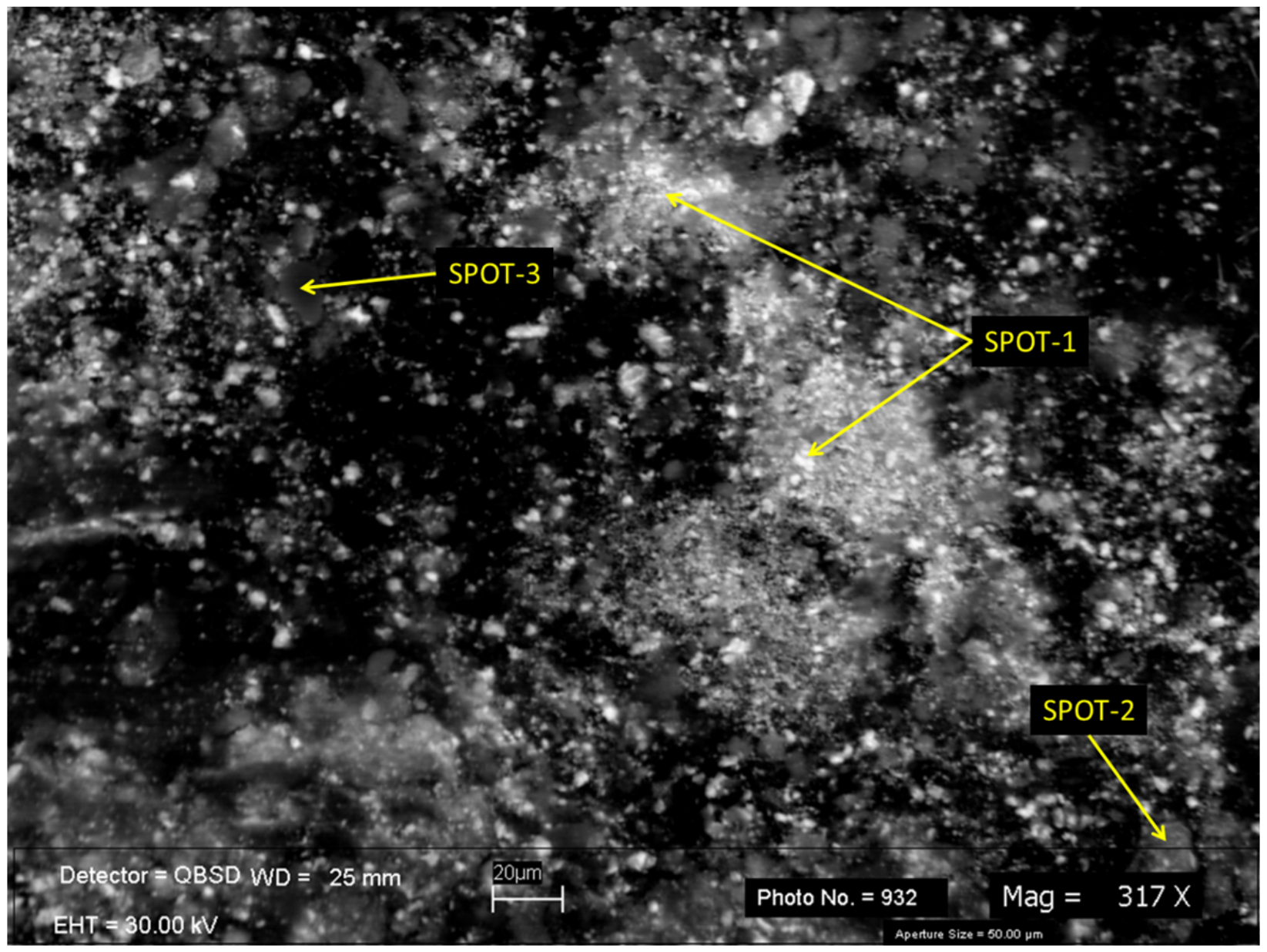

Figure 3-11. SEM image showing area of high Hg content (Spot 1) in formic acid leached SMECT PVV solids. 


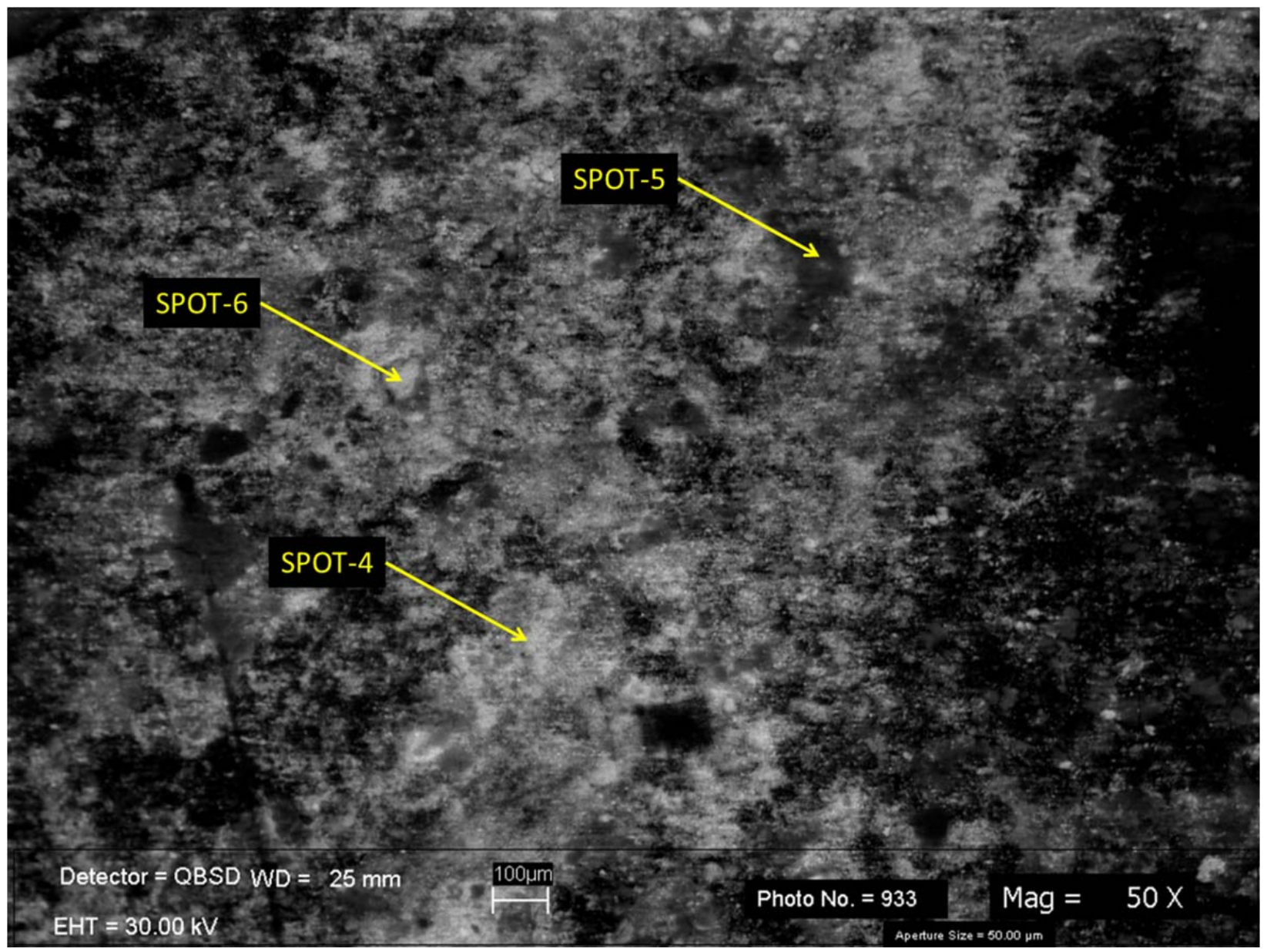

Figure 3-12. SEM image showing areas of Hg content (Spot 4, 5, and 6) in formic acid leached SMECT PVV solids.

\subsection{Unanswered Question}

What was not determined for the DWPF SMECT PVV sample was how much of the $18 \%$ loss on drying was due to moisture vs. possible elemental $\mathrm{Hg}$ loss. There was no visible sign of elemental $\mathrm{Hg}$, but the presence of an amalgam with other constituents in the sample cannot be ruled out with the information collected to date.

\subsection{Conclusions}

Based upon the SRNL analysis of the SMECT PVV jumper sample material, the following conclusions are put forth:

a) The sample material is a heterogeneous mixture of crystalline and non-crystalline species comprising approximately $82 \mathrm{wt} . \%$ total solids.

b) The order of abundance of elements in the sample is: $\mathrm{Hg}>>\mathrm{Al}>\mathrm{Fe}>\mathrm{Si}>\mathrm{Th} \approx \mathrm{Ni}$. The $\mathrm{Hg}$ species is non-crystalline and was not identified. 
c) The material is completely solubilized using a peroxide fusion digestion; mostly solubilized with a hot, pressurized aqua regia digestion leaving primarily Bohmite $[\mathrm{AlO}(\mathrm{OH})]$ undissolved; partially solubilized with $8 \mathrm{M}$ nitric acid leaving predominately Bohmite and Magnetite $\left[\mathrm{Fe}_{3} \mathrm{O}_{4}\right]$ undissolved along with other trace species; and a bit less partially solubilized with $90 \%$ formic acid leaving predominately Bohmite, Magnetite, and $\mathrm{Hg}$ species undissolved along with other trace species.

d) The dissolution test with $8 \mathrm{M}$ nitric acid resulted in significant dissolution of $\mathrm{Hg}$ from the material and an overall mass reduction of $\sim 52 \%$.

e) The dissolution test with $90 \%$ formic acid resulted in far less $\mathrm{Hg}$ dissolution from the material, as compared to the $8 \mathrm{M}$ nitric acid test, and an overall mass reduction of $\sim 31 \%$.

\subsection{Recommendations}

Of the two proposed remediation methods presented by DWPF to soak and flush the PVV line jumper, $8 \mathrm{M}$ nitric acid and $90 \%$ formic acid, our testing indicates the $8 \mathrm{M}$ nitric acid will have the most impact of the two. The nitric acid will dissolve at least an order of magnitude more $\mathrm{Hg}$ from the material, though some sludge components and frit present in the material will remain. The impact of a subsequent pressurized water rinse of the line could not be simulated, so its efficacy in removing the undissolved solids is unclear.

The collection and analysis of a sample of the $8 \mathrm{M}$ nitric acid soak/flush solution following contact with the line could be informative in assessing the relative success of the remediation effort. If the rinse is free of $\mathrm{Hg}$ and other elements, there was no pluggage material to remove. If the rinse contains significant $\mathrm{Hg}$ and/or solids one could conclude that there are contaminants present in the jumper line. Should the flush sample come back positive for the presence of solids, further sampling might not be able to determine whether the PVV jumper line is now clear of all materials after all flushing has been completed, this would require a visual inspection. 
SRNL-STI-2013-00289

Revision 0

\subsection{References}

1. Boyd, H. P. Analysis of Process Vessel Vent System Sample, HLW-DWPF-TAR-2013-0002, Savannah River Site, Aiken, SC 29808 (2013).

2. Coleman, C. J. Aqua Regia Dissolution of Sludge for Elemental Analysis. In Manual L 16.1, Procedure ADS-2226, Rev. 9, Savannah River National Laboratory, Aiken, SC 29808 (2009).

3. Coleman, C. J. Alkali Fusion Dissolution of Sludge \& Glass for Elemental and Anion Analysis, In Manual 16.1, Procedure ADS-2502, Rev. 6, Savannah River National Laboratory, Aiken, SC 29808 (2008).

4. Smith, G. L. Characterization of Analytical Reference Glass - 1 (ARG-1), PNL-8992, Pacific Northwest (National) Laboratory, Richland, WA (1993).

5. Bannochie, C. J., Imrich, K. J. DWPF GC Filter Assembly Sampling and Analysis, SRNL-STI2009-00602, Savannah River National Laboratory, Aiken, SC 29808 (2009). 


\section{Distribution:}

T. B. Brown, 773-A

D. R. Click, 999-W

A. P. Fellinger, 773-41A

S. D. Fink, 773-A

C. C. Herman, 999-W

E. N. Hoffman, 999-W

S. L. Marra, 773-A

F. M. Pennebaker, 773-42A

W. R. Wilmarth, 773-A

C. J. Bannochie, 773-42A

H. P. Boyd, 704-27S

J. M. Bricker, 704-27S

C. L. Crawford, 773-42A

T. L. Fellinger, 704-26S

E. J. Freed, 704-S

E. W. Holtzscheiter, 704-15S

J. F. Iaukea, 704-30S

D. K. Peeler, 999-W

J. W. Ray, 704-S

D. C. Sherburne, 704-S

M. E. Stone, 999-W

J. R. Zamecnik, 999-W

P. R. Jackson, DOE-SR, 703-46A

K. H. Subramanian, 766-H 